\title{
A POSTERIOR APPROACH FOR THE EXCISION OF SACRAL CHORDOMA
}

\author{
LEANDRO GENNARI, ALBERTO AZZARELLI, VITTORIO QUAGLIUOLO \\ From the Istituto Nazionale per lo Studio e la Cura dei Tumori, Milan
}

\begin{abstract}
We report eight cases of sacrococcygeal chordoma treated by high sacral resection through $\mathbf{S 2}$ by a posterior approach, with the intention of achieving radical removal. The technique we describe is easier than the combined abdominosacral approach, and there have been no serious intra-operative or postoperative complications.

The major technical problems were the margins of excision in the sacrum itself (one recurred) and in the perirectal soft tissues (four recurred), and the preservation of sacral nerve roots. When both $\mathbf{S} 2$ roots were preserved, sphincter problems were mild and reversible.

One patient died from recurrence 32 months after operation and one was lost to follow-up at eight months. Six patients are alive with a median survival of three years; three of them are free of disease after 22 , 36 and 80 months respectively. These results indicate the possibility of surgical cure of this malignant tumour.
\end{abstract}

Operation on malignant sacrococcygeal neoplasms seldom achieves radical excision, and the surgical approach is difficult because of the site and size of the tumour and its anatomical relation and involvement with surrounding tissues and organs. Chordoma is the most frequent primary malignant tumour of the sacrum, but the varied surgical approaches and treatment schedules which have been used without clear rationale make for difficulty in evaluating the results.

With the aim of improving the rationale for treatment, we report data on eight cases operated on with the same new diagnostic and surgical approach. This allows definition of anatomical margins and technical procedures which have given the best results in terms of local control of the tumour.

\section{MATERIAL AND METHODS}

Of 34 cases of chordoma seen in our institution, we now report our experience of eight cases which have been operated on since 1977, using the same surgical technique. All eight patients had a similar lesion and underwent high amputation of the sacrum distal to the inferior plate of the first or second sacral vertebra. The tumours were all larger than $12 \mathrm{~cm}$ in diameter (range 12 to $20 \mathrm{~cm}$ ) and involved almost all of the lower free

L. Gennari, MD

A. Azzarelli, MD

v. Quagliuolo, MD

Istituto Nazionale Tumori, Via Venezian 1, 20133 Milano, Italy.

Requests for reprints should be sent to $\operatorname{Dr} A$. Azzarelli.

(C) 1987 British Editorial Society of Bone and Joint Surgery $0301-620 \times / 87 / 4116 \$ 2.00$ portion of the sacrum and coccyx, protruding more anteriorly than posteriorly. A typical example of the size and relationship between the chordoma and the surrounding viscera is shown in Figure 1.

All operations were by a posterior approach, and though this is similar to the procedure reported by Sugarbaker (1982) for rectal cancer attached to the sacrum, there are important differences in incision, approach and exposure.

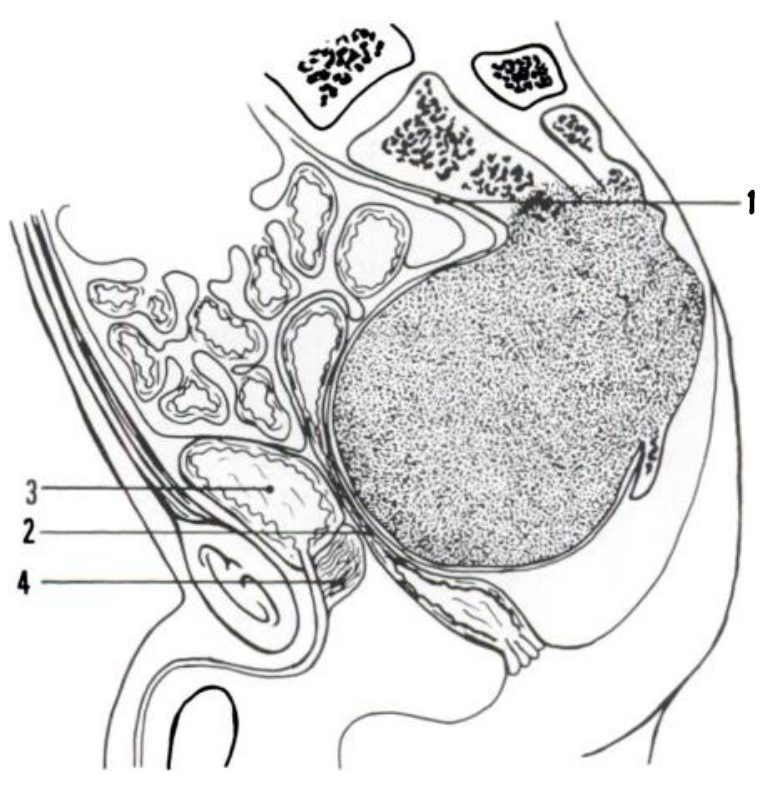

Fig. 1

To show the relation between a typical chordoma and the surrounding viscera. 1 , presacral lamina; 2 , rectum; 3 , bladder; 4, prostate. 
Pre-operative investigations. In addition to routine preoperative investigations, all the patients had tomography of the pelvis, CT scans, urography and a barium enema examination. Their neurological status was investigated with particular attention to sphincter function, perineal sensitivity, and motor power and sensation in the lower limbs.

Biopsy. The diagnosis of a malignant sacral bone tumour was often certain after clinical and radiological investigations; in one case open biopsy was avoided because it was obvious that surgical removal of the tumour was mandatory. In two cases, needle biopsy confirmed the malignant pattern of the lesion, which was suggestive of chordoma. Two cases had had a biopsy performed elsewhere, and in one of these the biopsy scar could not be removed en bloc with the surgical specimen. However, after 36 months' follow-up, there was no local recurrence in that area, which had been irradiated prophylactically. Intraoperative biopsy was not performed and is not recommended, since it is inadvisable to open the tumour in the surgical field.

Pre-operative preparation. The day before surgery, preparation with repeated enemas as for gastrointestinal surgery is recommended. Before the operation a vaginal pad is inserted into the rectum; this helps to identify the rectum during the operation, but the manoeuvre may be difficult in males because of the possibly narrow and angular path between the prostate and the bulky tumour (see Fig. 1).

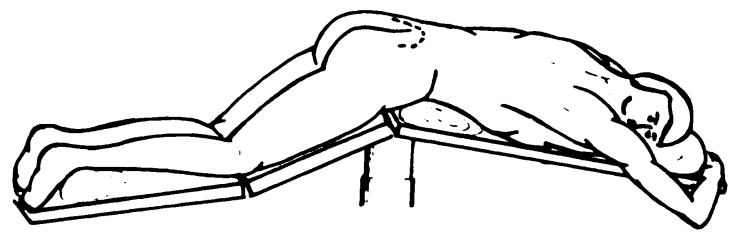

Fig. 2

Diagram of a patient in Kraske's position. The skin incision is indicated.

\section{Technique of operation}

The patient lies prone in Kraske's position (Fig. 2). The skin incision in five of our cases was transverse, arched upwards to give an inferiorly based skin flap. Of the three of our cases operated on with a downward-arched or a median vertical incision (MacCarty et al. 1961), two developed severe inflammatory complications, thought to be due to the vicinity of the anus and perineum. Wound infection is much more likely in the presence of faecal incontinence or sphincter problems during the immediate postoperative period. In addition, a vertical incision could injure the anal sphincter and gives no better exposure of the sacrum.

In contrast, of the five cases with upward-arched incisions, only one developed an infected haematoma and this settled with drainage and antibiotics, while in none of them was there any ischaemia of the skin flap.

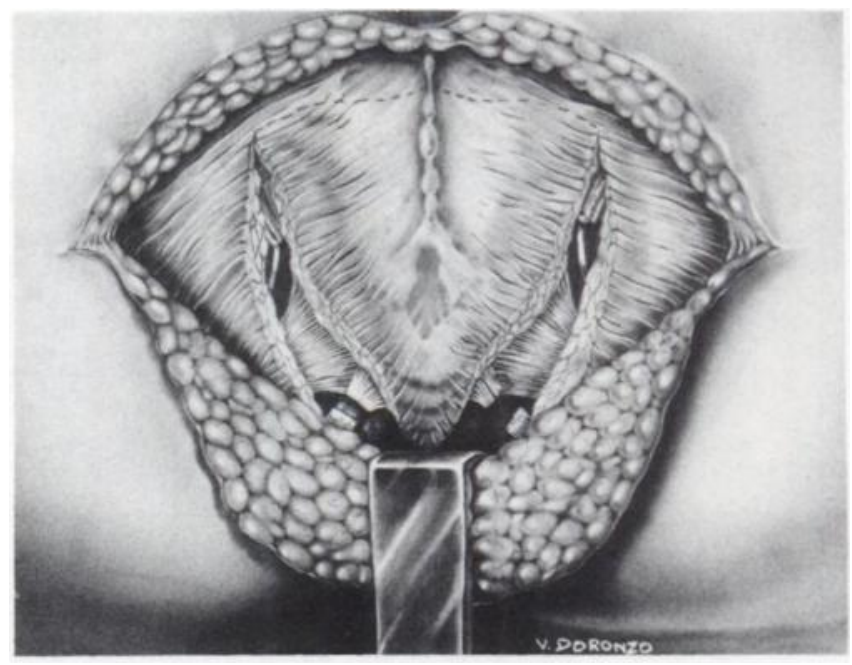

Fig. 3

The appearance of the sacrum after division of gluteus maximus and the sacrotuberous ligaments; the sacrospinous ligaments are seen; above and lateral to them are the $\mathbf{S 2}$ nerve roots.

When possible, the incision included excision of the biopsy scar.

The skin flap is prepared and raised, exposing the sacrum, the sacro-iliac ligaments, the origin of gluteus maximus, and the medial attachment of the sacrotuberous ligament. These ligaments and muscles, if uninvolved by tumour, are divided on both sides close to their sacral attachment. This allows exposure of the inferior roots of the sciatic nerves, the piriform muscles, and the posterior margin of the pelvic portion of the tumour. As much as possible of the muscle tissue of gluteus maximus is preserved to provide material to rebuild the posterior wall of the pelvis after the removal of the sacrum (Fig. 3).

At a deeper level, the piriform muscles and the sacrospinous and anococcygeal ligaments are found and divided, and the rectum is gently detached from the presacral lamina and from the tumour, which always protruded anteriorly. The easiest plane of cleavage is usually between the sacrum and the presacral lamina, but this plane should be avoided because the presacral fascia, even if not grossly involved, is often infiltrated by the tumour. Deep to this fascia, the rectum is gently isolated; it is highly vascularised by the haemorrhoidal plexus, and may bleed severely. In one case, a small accidental laceration of the rectum occurred; this was sutured immediately and gave no complications.

The upper level for section of the sacrum was decided in advance on the basis of the radiographs and CT scans. This level, as low as possible, but providing radical excision of the tumour, was never higher than the lower plate of the first sacral vertebra. At the chosen level, a careful digital dissection of the anterior soft tissue is performed on both sides through the greater sciatic notch below the lower margins of the ilium and the alae of the sacrum (Fig. 4). The bulky tumour usually remains well covered by the periosteum, and the careful finger 


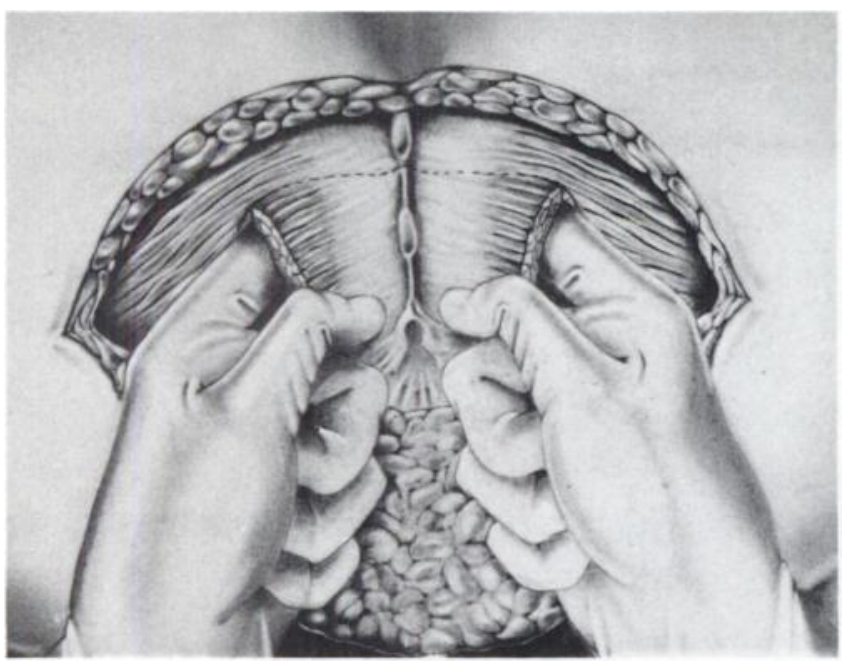

Fig. 4

To show the finger dissection of the anterior surface of the sacrum, just above the bulk of the tumour.

dissection avoids dramatic injury to the gluteal vessels.

When the surgeon's index fingers have contacted each other under the anterior face of the sacrum, the body of the sacrum is cut through with an osteotome (Fig. 5). This makes the resection specimen relatively mobile and the higher nerve roots, which are preserved, are easily visualised and carefully separated from the tumour. The lower roots, including S3, are removed en bloc with the tumour. The removed specimen includes the sacrum, coccyx, lower sacral roots and resected surrounding soft tissue (Fig. 6).

In five cases direct repair of the posterior wall and buttocks was achieved, but in three cases it was impossible to reconstruct a muscular wall behind the rectum. In one of these a tantalum net was used; however, severe draining infection occurred after adjuvant radiotherapy, and the prosthesis had to be removed. Better results were obtained with cadaver dura mater, which in two cases was well assimilated with no septic complications. Five patients were given adjuvant radiotherapy at doses ranging from 6200 to $7000 \mathrm{rad}$.

\section{RESULTS}

Details of our eight patients and the results to date as regards local recurrence and survival rate are reported in Table I. One patient was lost to outpatient follow-up after eight months, one died after 32 months, and six are alive with a median follow-up of 41 months (range 22 to 97 months); three of these patients are free of disease. The incidence of complications is discussed below.

\section{DISCUSSION}

Almost all the deaths from chordomas result from local recurrence, so greater effort to obtain adequate surgical excision is needed. In our experience most chordomas

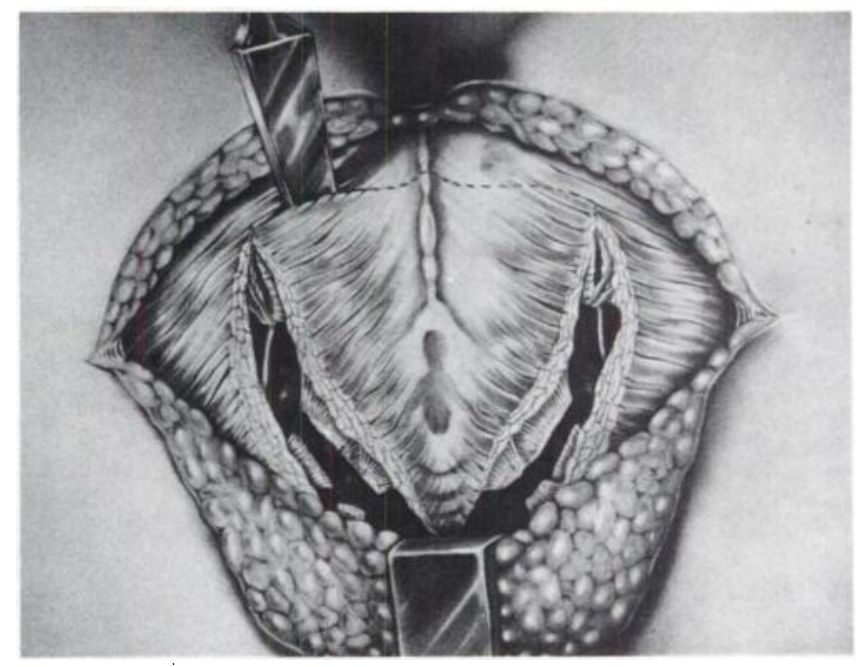

Fig. 5

The sacrospinous ligament and piriformis muscle have been divided and the anterior face of the sacrum at $\mathbf{S 2}$ to $\mathrm{S} 3$ has been cleared by bilateral blunt dissection. The free part of the sacrum is then amputated by use of an osteotome with great care to preserve the $\mathbf{S} 2$ nerve roots.

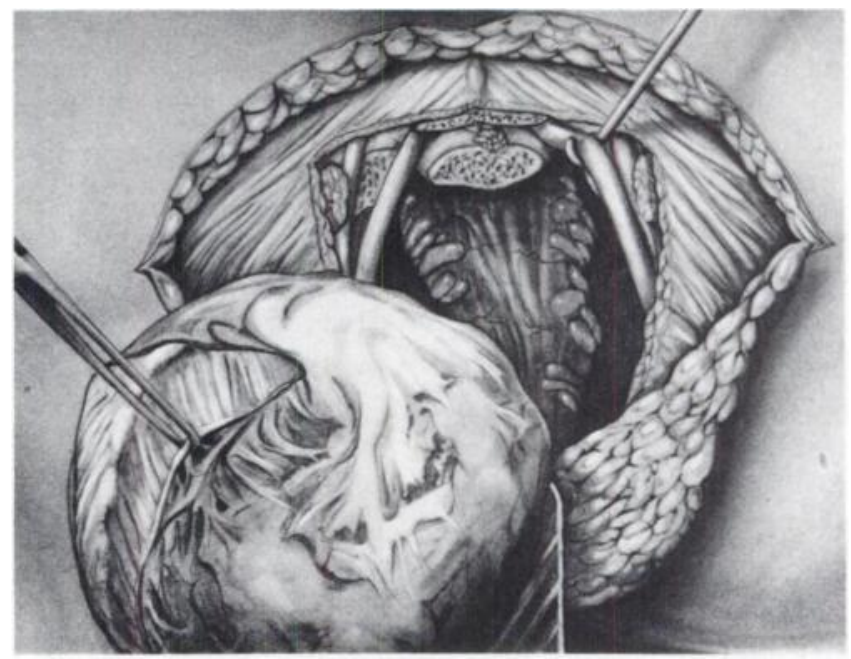

Fig. 6

After bone section, usually just below the inferior plate of the second sacral vertebra, the tumour can be displaced posteriorly or laterally and freed from the retroperitoneal soft tissues and the rectum. The specimen is then completely removed, while the $S 1$ and $S 2$ nerve roots and the rectum are preserved.

are large and involve most of the lower free portion of the sacrum and coccyx, protruding anteriorly like the submerged part of an iceberg. In all our cases, the tumour had displaced the retroperitoneal pelvic structures including the rectum, ureters, iliac vessels and nerves, but in no case was there any direct infiltration of these structures, and there were no postoperative problems with the sciatic nerve. The first sacral roots or the sciatic nerve were never involved, even if they were displaced or surrounded by the tumour.

High amputation of the sacrum inevitably results in bilateral resection of the inferior sacral nerve roots, the pudendal nerve and the coccygeal plexus. All the patients 
Table I. Details of 8 patients treated for sacrococcygeal chordoma

\begin{tabular}{|c|c|c|c|c|c|c|c|c|}
\hline $\begin{array}{l}\text { Case } \\
\text { number }\end{array}$ & Sex & $\begin{array}{l}\text { Age } \\
\text { (years) }\end{array}$ & $\begin{array}{l}\text { Clinical presentation } \\
\text { (duretion in months) }\end{array}$ & $\begin{array}{l}\text { Radiographic } \\
\text { site }\end{array}$ & Level of resection & $\begin{array}{l}\text { Adjurant } \\
\text { radiotherapy }\end{array}$ & $\begin{array}{l}\text { Local relapee } \\
\text { (months after } \\
\text { surgery) }\end{array}$ & $\begin{array}{l}\text { Outcome (months } \\
\text { afier surgery) }\end{array}$ \\
\hline 1 & $\mathbf{F}$ & 65 & Low back pain (6) & S3, 4 and 5 & $\begin{array}{l}\text { Under SI } \\
\text { Partial resection } \\
\text { of alae }\end{array}$ & No & Yes & $\begin{array}{l}\text { Died from recurrence (32) } \\
\text { Site unknown }\end{array}$ \\
\hline 2 & $\mathbf{M}$ & 63 & $\begin{array}{l}\text { Low back pain, then } \\
\text { mass (12) }\end{array}$ & $\begin{array}{l}\text { S4 and } 5 \\
\text { Coccyx }\end{array}$ & Under S2 & No & $\begin{array}{l}\text { Yes }(25) \\
\text { Treated with } \\
\text { radiotherapy }\end{array}$ & Living with disease (97) \\
\hline 3 & $\mathbf{M}$ & 37 & Low back pain (10) & S4 and 5 & Under S2 & $7000 \mathrm{rad}$ & $\begin{array}{l}\text { Yes (62) } \\
\text { Treated by } \\
\text { excision }\end{array}$ & No evidence of disease (80) \\
\hline 4 & $\mathbf{M}$ & 45 & $\begin{array}{l}\text { Low back pain ( } 37) \text {, } \\
\text { then sphincter } \\
\text { problems }\end{array}$ & S3, 4 and 5 & $\begin{array}{l}\text { Under } \mathbf{S 2} \\
\text { Tantalum net } \\
\text { repair }\end{array}$ & $6200 \mathrm{rad}$ & $\begin{array}{l}\text { Yes (7) } \\
\text { Resection } \\
\text { under S1 }\end{array}$ & Living with disease (43) \\
\hline 5 & $\mathbf{F}$ & 34 & $\begin{array}{l}\text { Sphincter problems } \\
\text { (12), then mass }\end{array}$ & S3, 4 and 5 & $\begin{array}{l}\text { Under S1 } \\
\text { Partial resection } \\
\text { of alae }\end{array}$ & $6500 \mathrm{rad}$ & No & No evidence of disease (39) \\
\hline 6 & $\mathbf{M}$ & 36 & $\begin{array}{l}\text { Low back pain (8), } \\
\text { sphincter problems } \\
\text { then mass } \\
\text { Trauma } 1 \text { year earlier }\end{array}$ & S3, 4 and 5 & Under S1 & No & $\begin{array}{l}\text { Yes }(7) \\
\text { Treated by } \\
\text { excision }\end{array}$ & Living with disease (36) \\
\hline 7 & $\mathbf{M}$ & 52 & $\begin{array}{l}\text { Low back pain }(18) \\
\text { Trauma } 10 \text { years } \\
\text { earlier }\end{array}$ & S3, 4 and 5 & Under S2 & $\begin{array}{l}\text { Yes } \\
\text { Dose unknown }\end{array}$ & Unknown & $\begin{array}{l}\text { Lost to follow-up } \\
\text { No evidence of disease at } 8 \\
\text { months }\end{array}$ \\
\hline 8 & $\mathbf{M}$ & 67 & $\begin{array}{l}\text { Low back pain ( } 5 \text { ) } \\
\text { Trauma } 3 \text { years earlier }\end{array}$ & S3, 4 and 5 & Under S2 & No & No & No evidence of disease (22) \\
\hline
\end{tabular}

we report had nerve root amputation below S2, though one case had unilateral preservation of S3, and two had unilateral resection of S2. Bilateral amputation preserving both $\mathrm{S} 2$ roots (five cases) resulted in perineal anaesthesia, with initial retention of urine and faecal incontinence. These troubles regressed more or less slowly and eventually almost normal sphincter function was regained.

The patient who had preservation of one $S 3$ root had prompt recovery of sphincter function. Both patients who had unilateral resection of S2 suffered saddle anaesthesia with reduced sensation in the posterior thigh on the same side. They had severe and continuous retention of urine with faecal incontinence; one required colostomy. The resection of the $\mathrm{S} 2$ root had occurred accidentally in each case during amputation of the sacrum. We prefer to use an osteotome or bone chisel for this rather than an oscillating drill or Gigli's saw, because the line of amputation is curved, and the manual control makes it possible to feel the consistency of the bone and thus reduce the risk of an intralesional resection.

According to the recent classification by Enneking, Spanier and Goodman (1980), all our excisions would be recorded as "marginal". The specimen at its anterior face was never really surrounded by a cuff of normal tissue, though a more radical excision was achieved in the sacrum itself. Recurrences involved either the body or the alae of the sacral remnant in only one case; in four cases they occurred around the rectum and lower buttock. These recurrences were usually easy to remove, but in three cases there was a second recurrence; two of these patients are at present living with their local disease.

Conclusions. The posterior approach for sacral tumours is feasible, faster, and more easily performed than the combined abdominosacral approach (Localio, Eng and Ranson 1980). High sacral resection can be radical provided that an adequate pre-operative evaluation is available and the second sacral vertebra is not involved. Further progress in operative treatment should be focused on the difficulties of radical surgery of the soft tissues of the retroperitoneal space; there may be an indication for excision of the rectum in selected cases. The role of postoperative irradiation cannot be assessed on the basis of this small series, but a more complete study of all our cases with adequate follow-up seems to confirm the validity of this adjuvant treatment (Azzarelli et al. 1987).

\section{REFERENCES}

Azzarelli A, Quagliuolo V, Cerasoli S, et al. Chordoma : natural history and treatment results in 33 cases. J Surg Oncol 1987; in press.

Enmeking WF, Spanier SS, Goodman MA. A system for the surgical staging of musculoskeletal sarcoma. Clin Orthop 1980;153:106-20.

Localio SA, Eng K, Ranson JHC. Abdominosacral approach for retrorectal tumors. Ann Surg 1980;191:555-60.

MacCarty CS, Waugh JM, Coventry MB, O'Sullivan DC. Sacrococcygeal chordomas. Surg Gynecol Obstet 1961;113:551-4.

Sugarbaker PH. Partial sacrectomy for en bloc excision of rectal cancer with posterior fixation. Dis Colon Rectum 1982;25:708-11. 